\title{
THE BENEFITS OF PHYSICAL ACTIVITY AND EXERCISE ON PHYSICAL, COGNITIVE AND DAILY LIFE ACTIVITIES IN AGING ADULTS
}

\author{
Dorjana ZERBO-ŠPORIN \\ University of Primorska, Faculty of Health Science, Izola, Slovenia \\ Corresponding Author: \\ Dorjana ZERBO-ŠPORIN \\ University of Primorska, Faculty of Health Science, Polje 42, 6310 Izola, Slovenia \\ Phone: +38656635463 \\ E-mail: dorjana.zerbosporin@fvz.upr.si
}

\section{ABSTRACT}

Due to increased longevity, degenerative diseases and disabilities have become one of the largest health care problem. The state of well-being with a low risk of premature health problems is important for successful aging. Even if the impact of physical activity and exercise on performance of daily life activities is still poorly understood, it seems that regular training has important benefits on physical and cognitive functioning in healthy elderly population. Combined training including strength, balance, flexibility exercises and activities that improve cardiorespiratory fitness, are important to ensure the independency of elderly people.

Keywords: physical activity, exercise, physical functioning, daily life activities, older adults 


\section{VPLIV GIBANJA NA TELESNE IN UMSKE SPOSOBNOSTI ZA IZVAJANJE VSAKODNEVNIH OPRAVIL V STAROSTI}

\section{IZVLE ČEK}

Ena izmed posledic podaljševanja povprečne življenjske dobe so tudi različne telesne omejitve in številne degenerativne bolezni, ki postajajo vse večji zdravstveni problem. Kvalitetno staranje je povezano z dobrim počutjem posameznika in nizkim tveganjem za zgodnji pojav bolezni. Vpliv redne telesne aktivnosti in vadbe na sposobnost izvajanja vsakodnevnih opravil v starosti še ni povsem pojasnjen, je pa vadba dokazano povezana z boljšimi telesnimi in kognitivnimi sposobnostmi starejše osebe. Kombinirani trening, ki vključuje vaje za moč, ravnotežje in gibljivost, v povezavi z rednimi vzdržljivostnimi telesnimi aktivnostmi, pomembno prispeva k ohranjanju samostojnosti starostnika.

Ključne besede: telesna aktivnost, telesna vadba, vsakodnevne telesne aktivnosti, starejše osebe

\section{INTRODUCTION}

European today can expect to live longer. According to Eurostat (2019) in 2017, one fifth (19\%) of the Europeans population was aged 65 and over. The share of elderly people tends to increase. Especially for those aged $80+$ years it will be more than double by 2080 to reach $13 \%$ of the whole population. The consequence of this increased longevity is that degenerative diseases and disabilities have become one of the largest health care problems. The negative impact of a longer life span is a potential for suffering physical frailty and it could become questionable whether life can be enjoyed fully under physical conditions that constrain daily activities (Spiduso, Francis, \& MacRea, 2005). The degree to which participation in physical activity (PA) and exercise translates into improved physical functioning and enhanced performance of daily life activities (ADL) is not yet clear. There is not a simple linear relationship between being active and being independent on others, but at least no increase in disabilities after being regular physically active was found (Chodzko-Zajko et al., 2009).

During aging structural and functional attenuation occurs in most physiological systems, even in the absence of diseases. These age-related changes can influence daily life activities through reduction in functional capacity. Advancing primary aging is mainly associated with the decline in PA volume and intensity, higher prevalence of degenerative conditions, body composition changes, and the decrease in maximal aerobic power. Aging is also characterized by the reduction in muscle strength and power and by the decline in flexibility, balance and cognitive functions (Shephard, 1997; Hunter, 
Dorjana ZERBO-ŠPORIN: THE BENEFITS OF PHYSICAL ACTIVITY AND EXERCISE ON PHYSICAL, COGNITIVE AND DAILY LIFE ..., 59-71

McCarthy \& Bamman, 2004; Chodzko-Zajko et al., 2009). At present, aging including loss of abilities is an inevitable process. There is, however, evidence that regular exercise has anti-aging effects. Target strength and aerobic training can attenuate a cardio-respiratory decline, muscle wasting and improve resistance to the development of disability with aging. Most common age-associated chronic conditions cause alteration in physiological functions and thus physiological interventions, of which physical exercise is a good example, can be a remedy (Tseng, 1995; Garatachea et al., 2015). Regular aerobic exercise improves endothelial function with increasing nitric oxide production and thus regulate vascular tonus. In addition, aerobic exercise stimulates angiogenesis and the reverse cholesterol transport. It increases heart rate variability, reduces activity of angiotensin II and inhibits blood coagulation. Resistance exercise improves muscle mass and strength in elderly. The molecular mechanisms involved are calcium flux, ATP/ADP ratio, intracellular $\mathrm{pH}$ redox balance. Post-exercise gene transcription mostly involves myogenic regulators. Exercise also attenuates neurodegeneration due to aging, by maintaining the hippocampal structure and upregulating neurotrophic factors, such as BDNF (brain derived neurotrophic factor) important for synaptic plasticity and cognitive performance (Garatachea, et al., 2015; Slutsky \& Etnier, 2016).

The primary goal of care for the elderly is to ensure their independent life as long as possible. There is evidence of an association among habitual PA in later life and the maintenance of effective functions (Wanderley et al., 2011).

\section{OBJECTIVES}

The aim of this article is to present a short overview of the literature regarding the benefits of PA and exercise on physical functioning and daily life activities in an adult, aging population. For this purpose, databases PubMed and Scopus were searched in February 2019 for literature sources published from 1995 to 2018 using research strategy: (physical activity OR exercise) AND physical functioning AND daily life activities AND older adults. A literature search was conducted including articles based on the following criteria: (1) clinical trials and reviews (2) published in English language. The research strategy generated 168 articles which were analyzed using the algorithm: review the titles, for the remaining review the abstracts and for the last remaining review the full text. Finally, 22 articles were selected to address the objective of the study: impact of physical activity and exercise on the ability to perform everyday task and independency in the elderly. Other relevant literature from the field was included.

\section{SUCCESSFUL AGING}

Successful aging (Rowe \& Kahn, 1997) is determined by three main components: low probability of disease and disease-related disability, high cognitive and physical functional capacity, and active engagement with life. Subjects are considered to suc- 
Dorjana ZERBO-ŠPORIN: THE BENEFITS OF PHYSICAL ACTIVITY AND EXERCISE ON PHYSICAL, COGNITIVE AND DAILY LIFE ..., 59-71

cessfully age if they can perform physical activities expected from an adult with no or little difficulties. Their ability to perform basic physical daily activities such: walking, stair climbing, bathing, dressing, doing housework, gardening etc. is usually valued through questionnaires (Strawbridge, Cohen, Shema, \& Kaplan, 1997). Physical reserve in old age is of a great significance and can be define as the distance from physical frailty: musculoskeletal function, aerobic capacity, and motor coordination decline. Individuals that still have sufficient physical reserve can continue to live in their homes and to carry out regular daily activities (Spiduso, Francis, \& MacRea, 2005). Cognitive reserve, the capacity to maintain healthy brain functions, is an important issue in successful aging. Identified components of cognitive reserve are childhood intelligence, higher mental ability, better management of stressful experiences, better use of health services, implementation of health education in lifestyle and a choice of cognitively more stimulating leisure activities. Managing the components that influence on cognitive aging and cognitive reserve is an important issue to maintain brain functions in old age (Whalley, Deary, Appleton, \& Starr, 2004). Especially hippocampus is important for cognitive performance. Studies have shown that maintaining a normal body weight and being physically active are beneficial for hippocampal structure and function (Slutsky \& Etnier, 2016). The state of well-being with a low risk of premature health problems is important for successful aging (Rowe \& Kahn, 1997).

\section{MAIN CONDITIONS THAT INFLUENCE DAILY LIFE ABILITIES IN OLDER ADULTS}

Decrease in bone and muscle mass, including faster decline in type II muscle fibers, decrease in tensile strength of tendons and ligaments, increase in muscle and related structure stiffness and the articular cartilage weakness are some of the most important aging conditions that influence daily life abilities in older adults (Shephard, 1997; Anish, 2009). Impairments in leg muscle power as well age - related decline in sensory capabilities, are important factors underlying mobility limitations in older adult daily life (Bean et al., 2004). Using bed rest as an aging model to study degenerative physiology of human systems we can follow physiological alterations at different ages. For example, the negative effect of bed rest on muscle mass and function was greater in older men, whereas metabolic disturbance was greater in younger adult men (Pišot et al., 2016). The available evidence suggests that bone mass reduction in the case of extreme physical inactivity represents an acceleration of the normal ageing of the bone and underlines the importance of being active to maintain tissue balance (Bilancio, Lombardi, Cirillo, Pišot, Rittweger, \& De Santo, 2012). There was no significant impairment in cognitive performance, mental health and satisfaction with life after the 14-day bed rest, except in the delayed recall of older adults (Dolenc \& Petrič, 2013). The obtained results provide evidence that favourable living, as well the quality of social interactions can protect against cognitive decline during physical inactivity (Dolenc \& Petrič, 2013; Dimec Časar, Tušak, \& Dolenc, 2015). When computerized cognitive training is being 
Dorjana ZERBO-ŠPORIN: THE BENEFITS OF PHYSICAL ACTIVITY AND EXERCISE ON PHYSICAL, COGNITIVE AND DAILY LIFE ..., 59-71

implemented during the bed rest study the improved in cognitive performance was evident and can successfully moderate detrimental bed rest effects in healthy older adults (Marušič et al., 2015; Marušič et al., 2017).

\section{PHYSICAL ACTIVITY TO IMPROVE PHYSICAL FUNCTIONING IN DAILY LIFE ACTIVITIES OF ELDERLY}

Healthy older adults who are able to engage in exercise can develop positive adaptations to the training. When compared to older adults (60-74 years), $73 \%$ of the reduction in total energy expenditure in nonagenarians is attributed to a reduction in PA level. The reduced physical activity in nonagenarians is associated with less physical functionality (Frisard et al., 2007). Nevertheless, multicomponent exercises including muscle power training enhance muscle mass, power output, and functional outcomes also in nonagenarians (Cadore et al., 2014).

Exercise, even at moderate level, in particular avoiding sedentary behavior, may delay disabilities and improve survival in older age. Types of activities that bring joy and are in the same time easy to include in daily life are suitable. For example, regular practice of daily life activities will allow their maintenance. Positive association was found among house/garden work and physical/mental well - being in older women (Peeters, van Gellecum, van Uffelen, Burton, \& Brown, 2014). Simple interventions like pet ownership are important in maintaining daily life abilities levels of older people (Raina, Waltner-Toews, Bonnett, Woodward, \& Abernathy, 1999). Even regular walking induces benefits for health, in addition is simple, safe and free of charge. We can walk anytime and anywhere: at home, up the stairs, in the nature in shopping malls (Drev, 2010). Dance, especially challenging dance programs are an effective countermeasure of aging on the brain. Dancing has a superior potential to induce more positive effects on brain volumes in elderly people to peperitive physical exercises (Rehfeld et. al., 2018). An important message is that exercises in old age are not beneficial only for physical functioning, but they also are neuro-protective (Herold, Törpel, Schega, \& Müeler, 2019).

But for most health outcomes, additional benefits occur as the amount of PA increases through longer duration, greater frequency and finally, higher intensity. Ideally, exercise programs for successful aging should include endurance training, resistance training and exercise for flexibility and balance (Simonsick, Guralnik, Volpato, Balfour, \& Fried, 2005; Chodzko-Zajko et al., 2009). In this case gradually increasing regular PA is extremely important. When preparing the training program, we must consider any health restrictions of the elderly subject (Gerževič \& Plevnik, 2014). The WHO guidelines are relevant to all healthy adults aged 65 years and over unless specific medical conditions: older adults should do at least 150 minutes (for additional benefits $300 \mathrm{~min}$ ) of moderate-intensity aerobic PA or do at least 75 minutes (for additional benefits 150 min) of vigorous intensity aerobic PA throughout the week. Aerobic activity should be performed in bouts of at least 10 minutes duration. Older adults should perform PA to 
Dorjana ZERBO-ŠPORIN: THE BENEFITS OF PHYSICAL ACTIVITY AND EXERCISE ON PHYSICAL, COGNITIVE AND DAILY LIFE ..., 59-71

enhance balance and prevent falls on 3 or more days per week. Muscle-strengthening exercise should be done on 2 or more days a week. When older adults cannot do the recommended amounts of PA due to health conditions, they should be as physically active as conditions allow (Global Recommendations on Physical Activity for Health - 65 years and above, 2011).

\section{Endurance activities for elderly}

Improvements in daily life abilities are often achieved by endurance training. Endurance exercises for elderly usually include brisk walking or jogging, swimming, yard work and dancing. Endurance training is an effective tool against the cardiorespiratory decline observed during aging. After an 8-year follow-up of older adults, Paterson, Govindasamy, Vidmar, Cunningham, and Koval (2004) report that a lower cardiorespiratory fitness is a significant determinant of becoming dependent. Authors suggest that initiatives to encourage physical activity in older adults should emphasize exercise to maintain or improve cardiorespiratory fitness. Thais de Lima, Corrêa Kanan, Augustin Schwanke, and Mânica da Cruz (2013) suggest that 3 months aerobic training program by treadmill walking result in significant increases in step length and self-selected walking speeds in healthy, independent, elderly women. Frequent, especially brisk pace walking is a relatively safe and easy activity also for hip fracture prevention (Feskanich, Flint, \& Willett, 2014). Aerobic exercise can improve physical performance but even a number of aspects of cognition and brain function (Hillman, Erickson, \& Kramer, 2008).

Heart rate is commonly used as a guide to exercise intensity. The American Heart Association suggest the target ranges for moderate-intensity exercise as $50 \%$ to $75 \%$ of average maximum heart rate. Exercise sessions should maintain target heart rate for 20 to 60 minutes (continuous or intermittent), with a minimum of $3 \times 10$-minute bouts collected throughout the day. According to American College of Sports Medicine, to achieve cardiorespiratory fitness aerobic exercise 3 to 5 days per week should be performed (McDermott \& Mernitz, 2004).

\section{Strength training for elderly}

Physical activity maintains muscular strength and endurance, flexibility and balance, all factors important for independent living of an elderly person. Generally, a progressive resistance training protocol can produce substantial increases in muscle strength and power of aging people (Skelton, Young, Greig, \& Malbut, 1995; Hanson et al., 2009). Leg strength and endurance are necessary for housekeeping, food preparation, shopping etc. Neuromuscular activation deficits precede changes in muscle size and strength, and this may be the initial mechanism that influences leg muscle power loss (Reid et al., 2014). A progressive resistance training program is effective in improving leg power in elderly men and women (Earles, Judge, \& Gunnarsson, 2001; Bean et al., 2004; Holviala et al., 2014). Furthermore, for improvement daily life activities of el- 
Dorjana ZERBO-ŠPORIN: THE BENEFITS OF PHYSICAL ACTIVITY AND EXERCISE ON PHYSICAL, COGNITIVE AND DAILY LIFE ..., 59-71

derly, a functional muscle power training program based on higher velocity movements that mimic daily life activities should be prescribed (Cress, Conley, Balding, HansenSmith, \& Konczak, 1996; Miszko et al., 2003; Bean et al., 2004; Henwood \& Taaffe, 2005). To combine, a progressive resistance training that incorporates rapid rate-offorce development movements may be safely undertaken in healthy older adults and results in significant gains in muscle strength, muscle power, and physical performance (Henwood \& Taaffe, 2005). Resistance exercises are powerful physical interventions to induce functional brain changes, especially by improvements in executive functions. Resistance exercises lead to mantain white matter and to smaller white matter lesions (Herold, Törpel, Schega, \& Müeler, 2019). Incorporating the elastic resistance training in nursing homes could be an effective strategy against functional decline during aging (Urzi, Marušič, Ličen, \& Bužan, 2019). Resistance training should be performed at least twice per week and exercises should target the major muscle groups. Patients can exercise all muscle groups at each session or divided the series into shorter sessions of 3 to 4 muscle groups that are worked on alternation, so 4-6 sessions per week. Each set should consist of 8 to 12 repetitions at a somewhat hard to harder intensity level using the Borg Rating of Perceived Exertion Scale. Sessions should be no longer than an hour, with 48 hours between sessions (McDermott \& Mernitz, 2004).

\section{Balance and flexibility training for elderly}

Combined exercises including strength, balance and flexibility exercises are effective in reducing the risk of falls (Campbell et al., 1997) and consequent limitations in daily life activity in old age. Flexibility is the range of motion around a joint and is associated with injury prevention. Of particular importance in aging is the maintenance of posterior thigh and ankle flexibility and of lower back flexibility. Appropriate flexibility can protect against chronic lower back pain and maintain the ability to perform daily life activities. Activities that improve flexibility include exercises that lengthen the muscles such as tai-chi, yoga, and stretching. A static stretching program including all major muscle groups performed a minimum of 2 to 3 times per week can improve agility and balance. Stretching exercises can be involved in warm-up and cool-down phases of an aerobic or resistance training (McDermott \& Mernitz, 2004). A fitness program that includes exercises to improve flexibility, and strength, with an emphasis on balance (for safety external support must be provided) involving the lower body muscles would be a good choice for elderly patient (McDermott \& Mernitz, 2004).

\section{PHYSICAL ACTIVITY PROGRAMS INCLUDING COGNITIVE TASKS}

Physical activity and exercise alone are neuro - protective (Guadagni et. al, 2018; Northey, Cherbuin, Pumpa, Smee, \& Rattray, 2018; Tyndall et. al., 2018; Herold, Törpel, Schega, \& Müeler, 2019), but less is known how to combine physical and cognitive 
Dorjana ZERBO-ŠPORIN: THE BENEFITS OF PHYSICAL ACTIVITY AND EXERCISE ON PHYSICAL, COGNITIVE AND DAILY LIFE ..., 59-71

training for greater effects on cognitive functions and how brain training alone influence mobility in older adults. Cognitive training itself can improve mobility-relatated outcomes in older adult, especially for challenging walking conditions (Marušič, Verghese, \& Mahoney, 2018). Physical activity programs for older adults can bring greater benefits when cognitive tasks are integrated. For example, challenging dance programs that combine aerobic fitness, sensorimotor skills and cognitive demands are promising in counteracting the decline in physical and cognitive abilities during aging (Müller et. al., 2017; Rehfeld et. al., 2018). Older adults should be made aware of the plasticity of the brain and the potential to maintain or improve their cognitive functioning when engage in mentally challenging physical activity (e.g. activities that combine physical and cognitive tasks as dance, tai-chi) (Gheysen et al., 2018). A systematic review of the effect of aerobic exercise on cognition in older adults showed an improving in auditory attention and cognitive processing speed (Angevaren et al., 2008). Physical activity, alone or combined with cognitive and nutritional interventions could enhance functional fitness in older adults (Paravlić, Marušič, Gerževič, Urzi, \& Šimunič, 2016). Simultaneous training of cognitive and physical abilities presents an important technique to improve cognitive and motor-cognitive performance, so offering a better basis on daily life functioning (Gerževič, Plevnik, \& Marušič, 2017). Even exercise at moderate level reduces the risk of developing cognitive impairment in older adults (Paterson, Jones, \& Rice, 2007). It seems that brain derived neurotrophic factors as metabotrophin mediate the effects of exercise on cognition (Gomez Pinilla, Vaynman, \& Ying, 2008). Although the effects of exercise on cognition are promising, information about the specific dose and type of exercise are still missing (Taylor, 2014).

Daily life abilities can be also impaired because of sleep disorders, which are common in elderly population. Regular physical exercise has been found as beneficial to initiating and maintaining sleep (Montgomery \& Dennis, 2002).

\section{CONCLUSIONS}

State of well-being with a low risk of premature health problems is crucial for successful aging. Even still poorly understood relationship between physical activity and performance of daily life abilities, it seems that regular training has important benefits on physical functioning and daily life abilities in healthy elderly population. In particular, a variety of resistance exercise trainings favorably impact walking and balance activities, through maintaining muscle strength, power and neuromuscular capability of aging people. An additional beneficial effect on physical functioning is achieved if rapid movements that mimic daily life abilities are incorporated in the training programs. Combined training including strength, balance and flexibility exercises are effective in reducing the risk of falls the consequences of which can very limited performance of daily life abilities in the old age. Old adults should be also encouraged to emphasize exercise, such as brisk walking, to maintain cardiorespiratory fitness, a significant de- 
Dorjana ZERBO-ŠPORIN: THE BENEFITS OF PHYSICAL ACTIVITY AND EXERCISE ON PHYSICAL, COGNITIVE AND DAILY LIFE ..., 59-71

terminant of healthy aging. Importantly, in the preparation of the training program is necessary to consider any health restrictions of the subject.

\section{REFERENCES}

Angevaren, M., Aufdemkampe, G., Verhaar, H. J. J., Aleman, A., \& Vanhees, L. (2008). Physical activity and enhanced fitness to improve cognitive function in older people without known cognitive impairment. Cochrane Database of Systematic Reviews, 3, 96 p. https://doi.org/10.1002/14651858.CD005381.pub2.

Anish, E. J. (2009). The senior athlete. In C. Madden, et al. (Eds.), Netter's sports medicine 1.ed. (pp 86-100), Philadelphia: Saunders, Elsevier.

Bean, J. F., Herman, S., Kiely, D. K., Frey, I. C., Leveille, S. G., Fielding, R. A., Frontera, W. R. (2004). Increased Velocity Exercise Specific to Task (InVEST) training: a pilot study exploring effects on leg power, balance, and mobility in community-dwelling older women. Journal of the American Geriatrics Society, 52(5), 799-804. https://doi. org/10.1111/j.1532-5415.2004.52222.x.

Bilancio, G., Lombardi, C., Cirillo, M., Pišot, R., Rittweger, J. \& De Santo, N. G. (2012). From space flights to osteoporosis. Annales Kinesiologiae, 3(1), 27-34.

Cadore, E. L., Casas-Herrero, A., Zambom-Ferraresi, F., Idoate, F., Millor, N., Gómez, M., ... Izquierdo, M. (2014). Multicomponent exercises including muscle power training enhance muscle mass, power output, and functional outcomes in institutionalized frail nonagenarians. Age, 36(2), 773-785. https://doi.org/10.1007/s11357-0139586-z.

Campbell, A. J., Robertson, M. C., Gardner, M. M., Norton, R. N., Tilyard, M. W., \& Buchner, D. M. (1997). Randomised controlled trial of a general practice programme of home-based exercise to prevent falls in elderly women. British Medical Journal, 315(7115), 1065-1069. https://doi.org/10.1136/bmj.315.7115.1065.

Chodzko-Zajko, W. J., Proctor, D. N., Fiatarone Singh, M. A., Minson, C. T., Nigg, C. R., Salem, G. J., Skinner, J. (2009). Exercise and physical activity for older adults. Medicine \& Science in Sports \& Exercise, 41(7), 1510-1530. https://doi.org/10.1249/ MSS.0b013e3181a0c95c.

Cress, M. E., Conley, K. E., Balding, S. L., Hansen-Smith, F., \& Konczak, J. (1996). Functional training: muscle structure, function, and performance in older women. Journal of Orhopaedic \& Sports Physical Therapy, 24(1), 4-10. https://doi.org/10.2519/ jospt.1996.24.1.4.

Dimec Časar, T., Tušak, M. \& Dolenc, P. (2015). Changes in mental health and satisfaction with life during physical inactivity induced by bed rest experiment. Annales Kinesiologiae, 6(1), 27-38.

Dolenc, P., \& Petrič, M. (2013). The effects of prolonged physical inactivity induced by bed rest on cognitive functioning in healthy male participants. Annales Kinesiologiae, 4(2), 129-143.

Drev, A. (2010). V gibanju tudi v starosti. Retrieved from: https://www.nijz.si/sl/ publikacije/v-gibanju-tudi-v-starosti. 
Dorjana ZERBO-ŠPORIN: THE BENEFITS OF PHYSICAL ACTIVITY AND EXERCISE ON PHYSICAL, COGNITIVE AND DAILY LIFE ..., 59-71

Earles, D. R., Judge, J. O., \& Gunnarsson., O. T. (2001). Velocity training induces power specific adaptations in highly functioning older adults. Archives of Physical Medicine and Rehabilitation, 82(7), 872-878. https://doi.org/10.1053/apmr.2001.23838.

Eurostat (2019). Population structure and aging. Retrieved from https://ec.europa.eu/eurostat/statisticsexplained/index.php/Population_structure_and_ageing.

Feskanich, D., Flint, A. J., \& Willett, W. C. (2014). Physical activity and inactivity and risk of hip fracture in men. American Journal of Public Health, 104(4), 75-81. https:// doi.org/10.2105/AJPH.2013.301667.

Frisard, M. I., Fabre, J. M, Russell, R. D., King, C. M., DeLany, J. P., Wood, R. H., \& Ravussin, E. (2007). Physical activity level and physical functionality in nonagenarians compared to individuals aged 60-74 years. Journal of Gerontology, 62A(7), 783-788. https://doi.org/10.1093/gerona/62.7.783.

Garatachea, N., Pareja-Galeano, H., Sanchis-Gomar, F., Santos-Lozano, A., Fiuza-Luces, C., ... Lucia, A. (2015). Exercise attenuates the major hallmarks of aging. Rejuvenation Research, 18(1), 57-89. https://doi.org/10.1089/rej.2014.1623.

Gerževič, M., \& Plevnik, M. (2014). Priporočila za vadbo v tretjem življenjskem obdobju. In M. Gabrijelčič Blenkuš, R. Situlin \& S. Pišot (Eds.), Telesna aktivnost in prehrana za kakovostno staranje [Physical activity and nutrition for quality aging] (pp 36-42). Retrieved from: http://www.zrs-kp.si/wp-content/uploads/2018/10/Pangea_GIBANJEATTIVITA.pdf.

Gerževič, M., Plevnik, M., \& Marušič, U. (2017). Benefits of motor and/or cognitive exercise: A review with recommendation for the third age. Annales Kinesiologiae, 8(1), 34-49.

Gheysen, F., Poppe, L., DeSmet, A., Swinnen, S., Cardon, G., De Bourdeaudhuij, I., ... Fias, W. (2018). Physical activity to improve cognition in older adults: can physical activity programs enriched with cognitive challenges enhance the effects? A systematic review and meta-analysis. International Journal of Behavioral Nutrition and Physical Activity, 15, 63-76. https://doi.org/10.1186/s12966-018-0697-x.

Global Recommendations on Physical Activity for Health - 65 years and above (2011). Retrieved from: https://www.who.int/dietphysicalactivity/physical-activity-recommendations-65years.pdf?ua=1.

Gomez-Pinilla, F., Vaynman, S., \& Ying, Z. (2008). Brain derived neurotrophic factor functions as a metabotrophin to mediate the effects of exercise on cognition. European Journal of Neuroscience, 28(11), 2278-2287. https://doi.org/10.1111/j.14609568.2008.06524.x.

Guadagni, M., Clark, C. M., Tyndall, A., Raneri, J.K., Parboosingh, J. S., Hogan, D. B., ... \& Poulin, M. J. (2018). Effects of six-month aerobic intervention on sleep in healthy older adults in the brain in motion study: a pilot study. Journal of Alzheimer's Disease Reports, 2(1), 229-238. https://doi.org/10.3233/ADR-180079.

Hanson, E. D., Srivastan, S. R., Agrawal, S., Menon, K. S., Delmonico, M. J., Wang, M. Q., \& Hurley, B. F. (2009). Effects of strength training on physical function: influence of power, strength, and body composition. The Journal of Strength and Conditioning Research, 23(9), 2627-2637. https://doi.org/10.1519/JSC.0b013e3181b2297b.

Henwood, T. R., \& Taaffe, D. R. (2005). Improved physical performance in older adults undertaking a short-term programme of high velocity resistance training. Gerontology, 51(2), 108-115. https://doi.org/10.1159/000082195. 
Dorjana ZERBO-ŠPORIN: THE BENEFITS OF PHYSICAL ACTIVITY AND EXERCISE ON PHYSICAL, COGNITIVE AND DAILY LIFE ..., 59-71

Herold, F., Törpel, A., Schega, L., \& Müeler, N. G. (2019). Functional and/or structural brain changes in response to resistance exercises and resistance training lead to cognitive improvements - a systematic review. European Review of Aging and Physical Activity, 16(10), 1-33. https://doi.org/10.1186/s11556-019-0217-2.

Hillman, C., Erickson, K. I. \& Kramer, A. F. (2008). Be smart, exercise your heart: exercise effects on brain and cognition. Nature Reviews Neuroscience, 9(1), 58-65. https:// doi.org/10.1038/nrn2298.

Holviala, J., Häkkinen, A., Alen, M., Salliner, J., Kramer, W., \& Häkkinen, K. (2014). Effects of prolonged and maintenance strength training on force production, walking, and balance in aging women and men. Scandinavian Journal of Medicine \& Science in Sports, 24(1), 224-233. https://doi.org/10.1111/j.1600-0838.2012.01470.x.

Hunter, G. R., McCarthy, J. P., \& Bamman, M. M. (2004). Effects of resistance training on older adults. Sports Medicine, 34(5), 329-348. https://doi.org/10.2165/00007256200434050-00005.

Marušič, U., Kavcic, V., Giordani, B., Gerževič, M., Meeusen, R. \& Pišot, R. (2015). Computerized spatial navigation training during 14 days of bed rest in healthy older adult man: Effects on gait performance. Psychology and Aging, 30(2), 334-340. https:// psycnet.apa.org/doi/10.1037/pag0000021.

Marušič, U., Giordani B., Moffat, S. D., Petrič, M., Dolenc, P., Pišot, R., \& Kavcic, V. (2017). Computerized cognitive training during physical inactivity improves executive functions in older adults. Aging Neuropsychology and Cognition, 25(1), 49-69. https:// doi.org/10.1080/13825585.2016.1263724.

Marušič, U., Verghese, J., \& Mahoney, J. R. (2018). Cognitive-based interventions to improve mobility: a systematic review and meta-analysis. Journal of the American Medical Directors Association, 19(6), 484-491. https://doi.org/10.1016/j.jamda.2018.02.002.

McDermott, Y. A., \& Mernitz, H. (2004). Exercise and the Elderly: Guidelines and Practical Prescription Applications for the Clinician Case Studies and Commentary. Journal of Clinical Outcome Management, 11(2), 117-128. Retrieved from: https://digitalcommons.calpoly.edu/kine_fac/51.

Miszko, T. A., Cress, M. E., Slade, J. M., Covey, C. J., Agrawal, S. K., \& Doerr, C. E. (2003). Effect of strength and power training on physical function in community-dwelling older adults. The Journal of Gerontology Biological Science \& Medical Science, 58(2), 171-175. https://doi.org/10.1093/gerona/58.2.M171.

Montgomery, P., \& Dennis, J. A. (2002). Physical exercise for sleep problems in adults aged $60+$. Cochrane Database of Systematic Reviews, 4, 1-14. https://doi. org/10.1002/14651858.CD003404.

Müller, P., Aye, N., Schmicker, M., Dordevic, M., Kaufman, J., Hökelmann, A., \& Müller, N. G. (2017). Dancing or FitnessSport? The effects of two training programs on hippocampal plasticity and balance abilities in healthy seniors. Frontiers in Human Neuroscience, 11, 1-9. https://doi.org/10.3389/fnhum.2017.00305.

Northey, J. M., Cherbuin, N., Pumpa, K. L., Smee, D. J., \& Rattray, B. (2018). Exercise interventions for cognitive function in adults older than 50: a systematic review with meta-analysis. Bitish Journal of Sports Medicine, 52(3), 154-160. https://doi. org/10.1136/bjsports-2016-096587.

Paravlić, A., Marušič, U., Gerževič, M., Urzi, F., \& Šimunič, B. (2016). The effects of different exercise-based interventions on functional fitness of older adults. Annales Kinesiologiae, 7(2), 117-137. 
Dorjana ZERBO-ŠPORIN: THE BENEFITS OF PHYSICAL ACTIVITY AND EXERCISE ON PHYSICAL, COGNITIVE AND DAILY LIFE ..., 59-71

Paterson, D. H., Govindasamy, D., Vidmar, M., Cunningham, D. A., \& Koval, J. J. (2004). Longitudinal study of determinants of dependence in an elderly population. Journal of American Geriatric Society, 52(10), 1632-1638. https://doi.org/10.1111/ j.1532-5415.2004.52454.x.

Paterson, D. H., Jones, G. R., \& Rice, C. L. (2007). Ageing and physical activity: evidence to develop exercise recommendations for older adults. Applied Physiology, Nutrition and Metabolism, 32(2E), 69-108. https://doi.org/10.1139/H07-111.

Peeters, G., van Gellecum, Y. R., van Uffelen, J. G. Z., Burton, N. W., \& Brown, W. J. (2014). Contribution of house and garden work to the association between physical activity and well-being in young, mid-aged and older women. British Journal of Sports Medicine, 48(12), 996-1001. https://doi.org/10.1136/bjsports-2012-091103.

Pišot, R., Marušič, U., Biolo, G., Mazzucco, S., Lazzer, S., Grassi, B., ... Šimunič, B. (2016). Greater loss in muscle mass and function but smaller metabolic alterations in older compared with younger men following $2 \mathrm{wk}$ of bed rest and recovery. Journal of Applied Physiology, 120(8), 922-929. https://doi.org/10.1152/japplphysiol.00858.2015.

Raina, P., Waltner-Toews, D., Bonnett, B., Woodward, C., \& Abernathy, T. (1999). Influence of companion animals on the physical and psychological health of older people: an analysis of a one-year longitudinal study. Journal of American Geriatric Society, 47(3), 323-329. https://doi.org/10.1111/j.1532-5415.1999.tb02996.x.

Rehfeld, K., Lüders, A., Hökelmann, A., Lessmann, V., Kaufmann, J., Brigadski, T., ... Müller, N. G. (2018). Dance training is superior to repetitive physical exercise in inducing brain plasticity in the elderly. PLoS ONE, 13(7), 1-12. https://doi.org/10.1371/ journal.pone.0196636.

Reid, K. F., Pasha, E., Doros, G., Clark, D. J., Patten, C., Phillips, E. M., ... Fielding, R. A. (2014). Longitudinal decline of lower extremity muscle power in healthy and mobility-limited older adults: influence of muscle mass, strength, composition, neuromuscular activation and single fibre contractile properties. European Journal of Applied Physiology, 114(1), 29-39. https://doi.org/10.1007/s00421-013-2728-2.

Rowe, J. H., \& Kahn, R. L. (1997). Successful aging. Gerontologist, 37(4), 433-440. https://doi.org/10.1093/geront/37.4.433.

Shephard, R. (1997). Aging, Physical Activity, and Health. Champaign, IL (USA), Human Kinetics.

Simonsick, E. M., Guralnik, J. M., Volpato, S., Balfour, J., \& Fried, L. P. (2005). Just get out the door! Importance of walking outside the home for maintaining mobility: findings from the womens health and aging study. Journal of American Geriatric Society, 53(2), 198-203. https://doi.org/10.1111/j.1532-5415.2005.53103.x.

Skelton, D. A., Young, A., Greig, C. A., \& Malbut, K. E. (1995). Effects of resistance training on strength, power, and selected functional abilities of women aged 75 and older. Journal of American Geriatric Society 43(10), 1081-1087. https://doi. org/10.1111/j.1532-5415.1995.tb07004.x.

Slutsky, A. B. \& Etnier, J. L. (2016). Caloric restriction, physical activity, and cognitive performance: A review of evidence and discussion of the potential mediators of BDNF and TrkB. International Journal of Sport and Exercise Psychology, 17(2), 1-17. https:// doi.org/10.1080/1612197X.2016.1223422.

Spiduso, W. W., Francis, K. L., \& MacRea, P. (2005). Physical dimensions of aging. Campaing, IL (USA), Human Kinetics. 
Dorjana ZERBO-ŠPORIN: THE BENEFITS OF PHYSICAL ACTIVITY AND EXERCISE ON PHYSICAL, COGNITIVE AND DAILY LIFE ..., 59-71

Strawbridge, W. J., Cohen, R. D., Shema, S. J., \& Kaplan, G. A. (1997). Successful aging: predictors and associated activities. American Journal of Epidemiology, 144(2), 134-144. https://doi.org/10.1093/oxfordjournals.aje.a008900.

Taylor, D. (2014). Physical activity is medicine for older adults. Postrgraduate Medical Journal, 90, 26-32. https://doi.org/10.1136/postgradmedj-2012-131366.

Thais de Lima, R., Corrêa Kanan, J. H., Augustin Schwanke, C. H., \& Mânica da Cruz, I. B. (2013). The effect of aerobic training on healthy elderly women's walking speed, step length and habitual physical activity. Pan American Journal of Aging Research, 1(2), 32-39. Retrieved from: http://revistaseletronicas.pucrs.br/ojs/index.php/ pajar/article/view/13287.

Tseng, B. S., Marsh, D. R., Hamilton, M. T., \& Booth, F. W. (1995). Strength and aerobic training attenuate muscle wasting and improve resistance to the development of disability with aging. The Journals of Gerontology, 50A (Special Issue), 113-119. https://doi. org/10.1093/gerona/50A.Special_Issue.113.

Tyndall, A., Clark, C. M., Anderson, T., Hogan, D. M., Hill, M. D., Longman, R. S., \& Poulin, M. J. (2018). Protective effects of exercise on cognition and brain health in older adults. Exercise and Sport Sciences Reviews, 46(4), 215-223. https://doi.org/10.1249/ JES.0000000000000161.

Urzi, F., Marušič, U., Ličen, S., \& Bužan, E. (2019). Effects of elastic resistance training on functional performance and myokines in older women - a randomized controlled trial. Journal of the American Medical Directors Association, 20(7), 830-834. https:// doi.org/10.1016/j.jamda.2019.01.151.

Wanderley, F. A. C., Silva, G., Marques, E., Oliveira, J., Mota, J., \& Carvalho, J. (2011). Associations between objectively assessed physical activity levels and fitness and selfreported health-related quality of life in community-dwelling older adults. Quality of Life Research, 20(9), 1371-1378. https://doi.org/10.1007/s11136-011-9875-x.

Whalley, L. J., Deary, I. J., Appelton, C. L., \& Starr, J. M. (2004). Cognitive reserve and the neurobiology of cognitive aging. Aging Research Review, 3(4), 369-382. https://doi. org/10.1016/j.arr.2004.05.001. 